\title{
Two Sources of Antiwar Sentiment in America ${ }^{1}$
}

\author{
Howard Schuman
}

University of Michigan

\begin{abstract}
Opposition to the Vietnam war has been manifested both in university protest actions and in cross-section public opinion surveys. But the college-related protests and the wider public disenchantment have sharply different characteristics: they have peaked at different points in the war; they are discontinuous in educational and age basis; and a substantial part of the antiwar public is also extremely hostile toward college protesters. Together these findings suggest a distinction between moral criticisms of the goals and nature of the war and pragmatic disillusionment over failure to win it. This hypothesized distinction is investigated using thematic analysis of open-ended responses from a cross-section sample of 1,263 Detroit adults who had indicated opposition to American intervention in Vietnam. A small classroom sample of University of Michigan students is also used for comparison purposes. The themes emphasized by the Detroit sample as a whole, and by most subcategories defined in terms of race, sex, age, and education, are generally consistent with the moral-pragmatic distinction. Other related factors (such as traditional isolationism) are also shown to contribute to broader public disenchantment with the war. The moral-pragmatic distinction, while somewhat oversimplified, is useful in considering public reactions to future wars of the same general type.
\end{abstract}

Two distinct measures of opposition to American involvement in Vietnam can be traced over the past seven years. One is the intensity and scope of college-related protests against the war. The other comprises the results of Gallup polls and similar opinion surveys based on cross sections of the entire American adult public. Both measures show increasing disenchantment with the war, and it is easy to treat them as simply two aspects of the same thing. There is some truth to this, but even more error. The college-based protest has focused on moral objections to the use of American military power in Vietnam. The general public disenchantment, however, seems to have been largely practical, springing from the failure of our substantial military investments to yield victory. Confusing these two sources of opposition to the war leads to serious

${ }^{1}$ A version of this paper was given at the American Sociological meetings, New Orleans, August 1972. The paper draws on data collected in the 1971 Detroit Area Study, carried out in collaboration with Otis Dudley Duncan, and supported by funds from the Russell Sage Foundation and from the University of Michigan. I am indebted to Elizabeth Fischer and Sunny Bradford, who helped in the development of the Vietnam codes, and to Mark Tannenbaum, who aided in the analysis. 
miscalculations about the relationship between mass opinion and presidential action in matters of war and peace.

\section{THREE DIFFERENCES BASED ON PAST SURVEY FINDINGS}

The first major campus protest occurred in March 1965 at the University of Michigan. A handful of faculty members and students created the "teach-in" as a way of arousing opposition to the recently initiated bombing of North Vietnam. Several thousand members of the university community attended the all-night series of lectures and discussions about the war, concluding on an emotional note with songs and oratory. Above all, there was a strong tone of moral indigation in the teach-in. The United States was pictured as intervening in what was essentially a civil war, supporting a corrupt and unpopular government, and now extending the war dangerously by sending modern bombers to pound the countryside of North Vietnam. The main issue presented was not whether the United States could win the war but rather the devastation that such a victory would entail.

Similar protests spread rapidly in the next months to other major campuses. Later, they expanded beyond the campus and led to massive demonstrations in Washington, New York, and other cities. This expansion was characterized by the same moral emphasis seen in the first teach-in. A whole generation of students, especially at major universities, is learning to criticize our involvement in Vietnam as not merely unsuccessful but also morally wrong.

It is commonly assumed that the public slept until awakened by the college protests. Since then, public opinion is thought to have moved in much the same direction, though more slowly, and with uncertainty and occasional backtracking. This movement of national opinion can be traced by the one question that the Gallup organization has repeated regularly since 1965:" "In view of the developments since we entered the fighting, do you think the United States made a mistake in sending troops to fight in Vietnam?" Results for this question show a large and unmistakable trend in growth of opposition to the war over the seven-year period. In August 1965 , only $24 \%$ of the population believed our intervention a mistake; by May 1971 that figure had climbed well past a majority to $61 \%$.

So far it appears that public opinion has followed much the same course as the college protest. But a closer look at dates and events reveals some

2 These and other Gallup findings reported came from the monthly publication Gallup Opinion Index. Further descriptive analysis of these results and of related data from the University of Michigan Survey Research Center and other sources can be found in Converse and Schuman (1970), Davis (1970), and Mueller (1971). 
important differences. The first teach-in, for example, was created to protest a major new employment of military force by the United States-the bombing of North Vietnam. The countrywide campus strikes in May 1970 were directed in good part against still another example of expanding American military power-the thrust into Cambodia. These two examples reflect the fact that university protests have been provoked primarily by anger and dismay over offensive military actions by the United States.

When we search the polls for similar turning points in the trend of general public opinion, we find them at different locations. The most dramatic change in survey trends on the war is best reflected by a "hawkdove" question that Gallup administered at several points in 1968 and 1969: "People are called 'hawks' if they want to step up our military effort in Vietnam. They are called 'doves' if they want to reduce our military effort in Vietnam. How would you describe yourself-as a hawk or a dove?" Just before the Tet attacks in January 1968, with American leaders confidently predicting victory, the number of self-described hawks outnumbered doves by two to one. But two months after Tet the proportion of doves in the country slightly exceeded that of hawks, and by the end of the same year, doves outnumbered hawks by nearly two to one. The shift in a space of just 60 days represents probably the largest and most important change in public opinion during the entire war. ${ }^{3}$ (The "mistake" question quoted above also reveals a sharp drop in support for the war over the first eight months of 1968; the slope is less precipitous probably because the question was less fitted to immediate policy directions.) These transformations came, it will be noted, not in reaction to expanding American power, but in response to a widely advertised American defeat. ${ }^{4}$ It is almost as though a sizeable number of Americans had

3 The figures for several key dates are:

\begin{tabular}{llccccc}
\hline \hline & & Hawks & Doves & No Opinion & Total \\
\hline (a) January $1968 \ldots \ldots \ldots \ldots \ldots \ldots \ldots$ & 56 & 28 & 16 & 100 \\
(b) March $1968 \ldots \ldots \ldots \ldots \ldots \ldots$ & 41 & 42 & 17 & 100 \\
(c) April $1968 \ldots \ldots \ldots \ldots \ldots \ldots \ldots$ & 41 & 41 & 18 & 100 \\
(d) November $1969 \ldots \ldots \ldots \ldots \ldots$ & 31 & 55 & 14 & 100 \\
\hline
\end{tabular}

The Tet Offensive occurred between the $(a)$ and $(b)$ measurement points, while President Johnson's announcement of a partial bombing halt (and his decision not to seek reelection) occurred between $(b)$ and $(c)$. Thus the decisive change in early 1968 seems attributable to the offensive itself, rather than to the presidential policy announcements. The subsequent decline in number of hawks over the next year and a half is no doubt more complicated and represents the basic acceptance by both political parties of the bombing halt, the Paris talks, and later the troop withdrawals. By the end of 1968, almost all political leaders had become "doves," at least in rhetorical expression.

4 Oberdorfer (1971) offers a persuasive case for the official American interpretation of Tet as a military defeat for the Viet Cong and North Vietnamese. But he also 
suddenly concluded that the war was not about to be won by being "stepped up," and that hence the only alternative was to step it down. More generally, the curve of broad public disenchantment with the war seems to reflect not offensive actions but news of defeats, casualties, and frustrations. ${ }^{5}$

A second divergence between campus-related protests and general public opinion appears in the reaction of the public to antiwar demonstrators. The gathering of more than a quarter million people in Washington in November 1969 drew heavily from colleges and universities but was intended as evidence of the extent of opposition across the country to the administration's prolongation of the war. Great pains were taken to keep the demonstration peaceful, so that it would appeal to the public at large. Yet the following month the Gallup Poll showed a $6 \%$ rise in public approval "of the way President Nixon is handling the situation in Vietnam." The president's speech a few days before the march undoubtedly had some influence in rallying public opinion to his side. But there is also reason to think that the demonstration itself had a negative effect on parts of the public unhappy with the war but even unhappier with demonstrators.

Poll data show clearly that open protest against the war is not well regarded by the great majority of American adults. In 1968 the University of Michigan Survey Research Center asked a national sample to indicate their "feelings" toward "Vietnam war protesters" on a scale ranging from zero (very unfavorable) to 100 (very favorable), with a neutral midpoint of 50. It is perhaps no great surprise that seven out of every 10 adults placed protestors on the negative half of the scale. What may seem strange is that extreme dislike of war protestors was shown by many people who on other questions indicated their own opposition to the war. For example, one question in the survey asked "Which of the following do you think we should do now in Vietnam?" Three alternatives were given:

1. Pull out of Vietnam entirely.

2. Keep our soldiers in Vietnam but try to end the fighting.

3. Take a stronger stand even if it means invading North Vietnam.

documents graphically the way in which the Communist offensive was interpreted by the American public as new and dramatic evidence that the war was far from over and far from being won.

5 Mueller (1971) suggests that both the Korean and the Vietnam wars can best be explained in terms of an initial "rally round the flag" enthusiasm, followed by a drop in support as the costs, frustrations, and length of each war became clear. The Chinese intervention in Korea had an impact even greater than Tet in shattering expectations of a quick and decisive victory. Mueller seems to argue against the importance of any single similar traumatic event for the Vietnam war, but he does not deal explicitly with Tet, or with the hawk-dove question we have reviewed here. 
Of those who chose the first response, calling for unilateral withdrawal, more than half nevertheless placed "Vietnam protestors" on the negative side of the feeling scale. One out of four of these extreme doves placed protestors at the absolute bottom of this 100-point scale. These findings raise serious questions about the effect of massive antiwar demonstrations. When the television cameras focus on the protestors themselves, rather than on the object of protest, Vietnam, the demonstrations probably lead many people who are against the war toward support for the president.

One more important set of findings from national surveys points to the divergent types of antiwar sentiment. As we have already noted, the most forceful dissent over Vietnam has come from students and faculty in leading universities. These articulate opponents of the war have tended to assume that their potential allies in the general public are the most educated and informed segments of the population. Such is indeed the case on many issues-for example, questions involving civil libertieswhere the universities provide forward positions which then find public support in direct proportion to the education of those questioned (Stouffer 1955).

Contrary to common belief, however, this has not been the case with the Vietnam war. Analysis of poll data shows more educated sections of the public to have generally provided the greatest support for continuing American involvement. In February 1970, for example, Gallup asked its national sample: "Some U. S. Senators are saying that we should withdraw all our troops from Vietnam immediately-would you favor or oppose this?" Of those having an opinion, more than half the gradeschool-educated adults favored immediate withdrawal, about two-fifths of those with high school backgrounds, and only $30 \%$ of those with at least some college. This was not a fluke. In May 1971, 66\% of those college-educated persons with opinions claimed that the war was a mistake, but the figure rose to $75 \%$ among the grade-school-educated. In general, a careful review of public opinion data over the last seven years shows that on most war-related issues, the greatest opposition to continued American involvement in Vietnam has come from the least educated parts of the population. ${ }^{6}$

A related finding is that when it comes to Vietnam, the "generation gap," at least in a simple form, has been largely a myth. Age differences in the general public have been neither great nor consistent. On the

6 The socioeconomic findings from survey data are supported by the results of census tract analysis using cities and towns that have carried out referenda on the Vietnam war (Hahn 1970). More detailed analysis within the college category reveals that opposition has been great in high-quality college groups, exactly as one would expect from the fact that the protest movement began at such places as Columbia, Harvard, and Michigan (see Converse and Schuman 1970; Robinson and Jacobson 1969). 
question about immediate withdrawal mentioned above, those under 30, those 30-49, and those over 50 all show much the same pattern of responses. More recently, young people do call for a faster rate of withdrawal, but older people continue to be more likely to regard the war as a mistake.

What sense can we make out of these poll results, especially when they contradict what our eyes and ears reveal about the intensity of antiwar feeling among youth on college campuses? The first thing to realize is that college students comprise less than half the college-age population in the United States. More particularly, it would be quite possible to have every student in the major universities in complete opposition to the war, yet find the total college-age population showing strong support. To this we must add the obvious but easily forgotten fact that in national surveys, "college"-educated persons are primarily adults who are well past college age at present, so that we cannot expect them to reflect recent changes on campuses.

Once we realize that students (and faculty) at Columbia, Michigan, or Berkeley cannot tell us much about the degree of public opposition to the war, we must also recognize a more subtle point: the basis for disenchantment with Vietnam need not be the same in the general population as on the campus. Why, indeed, is there public opposition to the war? This is such a simple-minded question that it may seem absurd even to raise it. The fact is, however, that we do not know the answer. Gallup and other polls have documented well the growing negative sentiments on the war, but almost no effort has been made to explore the reasons behind these sentiments. Such exploration requires open-ended questions that ask people to state in their own words why they hold a particular policy position. ${ }^{7}$ Questions of this sort, however, are expensive to include in interviews and complex to analyze and report. Unfortunately, their omission has a more dangerous effect than simply leaving us ignorant, for in the absence of knowledge of public opinion we all have a tendency to project our own views onto the population as a whole. This is particularly true when one tries to interpret the reasons behind a position with which one agrees. If one feels that American involvement in Vietnam was a mistake and then reads that two-thirds of the population also says that it was a mistake, it is quite natural to assume the reasons are the same in both cases. But of

7 The other alternative is structural analysis of a large set of interrelated closed questions, as is done insightfully by Modigliani (1972) on poll data from the Korean War period. Ideally both approaches should be used. In the present case, where we are attempting to discover basic frames of reference, it seems to me, as it did to Robinson and Jacobson (1969), essential to be able to draw on relatively unprompted verbalizations by respondents. Of course, both these approaches deal with overt "reasons" and "goals," and still further analysis of social and psychological motives is possible; some steps in this direction are indicated later. 
course this need not be true, any more than it is true that votes for a Democratic presidential nominee by Mississippi whites and New York blacks spring from the same motives and concerns.

\section{A BROAD HYPOTHESIS}

In the summer of 1971 the Detroit Area Study included an open question to provide some insight into the basis of public thinking about Vietnam. Before reviewing those data, let us summarize in the form of a general hypothesis the argument developed thus far. We have seen that public opinion has been turned against the war mainly by reversals such as the Tet offensive. It is also clear that a good part of the public now opposed to the war is also opposed to the antiwar protests and, presumably, the beliefs that they symbolize. Finally, we have found that the larger public opposition to the war includes a substantial proportion of people who are low in education, not very interested in the war, and about as likely to be older as to be younger. ${ }^{8}$ What these several pieces of evidence suggest is that much of the disenchantment with the war registered in public opinion polls is of a purely pragmatic character, with little or no concern over the morality of employing American power in Vietnam. Disenchantment with the war is based on our visible lack of success in winning it. Mounting American casualties, the failure of so many optimistic predictions by American leaders, the surprising resilience of enemy forces - all these factors have taken their toll in supporters of the war. More and more Americans now think our intervention was a military mistake, and want to forget the whole thing. This explains why the Tet offensive had such a disastrous effect on public opinion, while the My Lai massacre caused hardly a ripple in the polls.

We can also understand in these terms why almost any administration action that seems to point toward an end to the war wins at least a brief rise in public support. When American planes first crossed the North Vietnam border, the public hoped that a serious blow had at last been struck against enemy sanctuaries. We lack adequate survey data from that period, but what data we have suggest wide support for the bombing. Five years later, when American troops crossed the Cambodian border, a less optimistic public still showed initial acceptance of another president's claim to be reaching important enemy sanctuaries. ${ }^{9}$ In between and subsequently,

8 On "interest" in the war, see Converse and Schuman (1970) and, using earlier data, Verba et al. (1967).

${ }^{9}$ At the time of the Cambodian incursion (May 1970), about $50 \%$ of the public regarded our original intervention in Vietnam as a mistake. But a very similar question asked by Harris (1971, p. 124) about Cambodia in May 1970 produced only $39 \%$ who thought this new military action was a mistake. By July 1970, even this 
almost every action that promised to hasten the end of the war, retreats as well as offensive actions, has won support from a large part of the public.

The distinction between moral and pragmatic opposition to the war is blurred by the policies of troop withdrawal, since these tend to be supported by both viewpoints. But the invasion of Cambodia could appeal only to the pragmatic opponent of the war. Provided he accepted the president's assurance that "cleaning out the sanctuaries" would speed troop withdrawals, the pragmatic objector could support the invasion. To the moral opponent of the war, however, the Cambodian intervention, no matter how limited in time or successful in outcome, meant that the destruction of war was now to be brought to Cambodian villages. On this issue, on the more recent American bombing, and perhaps on issues still to come, the different sources of opposition to the war lead to sharply different stands even among the majority who want an early end to American involvement.

\section{METHOD AND SOURCE OF DATA}

Let us turn now to the reasons that the general public gives for opposing the war. From April through August 1971, the Detroit Area Study interviewed an area probability cross-section sample of 1,881 persons, 21 years old and over, in the metropolitan Detroit area. ${ }^{10}$ The interview included the Gallup "mistake" question discussed earlier; it was followed by open probe questions to those who said they thought our sending troops to Vietnam was a mistake. The probes were simply: "Why would you say it was a mistake?" and "Is there any other reason why you think it was a mistake?" The instruction to interviewers was to be completely nondirective but to encourage full responses. The resulting verbal data from the 1,263 respondents who said "yes" to the closed question have been coded in terms of 10 broad themes developed partly on the basis of theoretical expectation and partly after carefully reviewing 100 responses chosen at random. In the final coding, each of the 1,263 responses was coded zero for a particular theme if that theme was not mentioned; if the theme was mentioned, the response was further categorized in terms of the way the theme was treated. Table 1 presents the five themes that are most relevant for our analysis, along with the marginal percentages for the metropolitan

$39 \%$ had shrunk to $24 \%$, presumably on the basis of reports that the incursion had ended and had been relatively successful. Thus doubts about Vietnam did not prevent hope for the success of a similar military operation in another country.

10 A report on the sampling design for the 1971 survey can be obtained from the Detroit Area Study, University of Michigan, Ann Arbor. The geographic area covered is the Detroit Standard Metropolitan Statistical Area (SMSA), minus the city of Pontiac and the outlying semirural areas of the three-county area; it includes about $85 \%$ of the SMSA population. 
TABLE 1

Reasons against U.S. Intervention: Major Themes Coded (with Percentages for Detroit Sample)

Theme

I. U.S. Not Winning War:

0 . Theme not mentioned $\ldots \ldots \ldots \ldots \ldots \ldots \ldots \ldots \ldots \ldots \ldots \ldots$

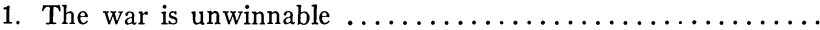

Example: "It can't be won militarily; it's guerilla warfare, not like World War II or Korea."

2. We are not trying to win the war $\ldots \ldots \ldots \ldots \ldots \ldots \ldots \ldots$ "Win or get out."

3. We are not winning (stated as a fact with no additions) .... "We're just getting beat like crazy."

4. The war is not ending (low priority relative to $1,2,3$ ) $\ldots \ldots$. "The war just goes on and on."

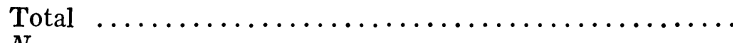

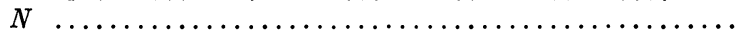

II. People Killed or Injured by the War:

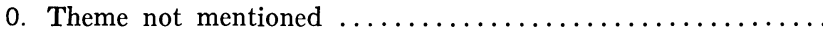

1. American soldiers killed or injured $\ldots \ldots \ldots \ldots \ldots \ldots \ldots \ldots$ "So many boys being killed."

2. American soldiers hurt in other ways $\ldots \ldots \ldots \ldots \ldots \ldots \ldots$ "All those soldiers getting the dope habit."

3. People killed or injured: identity ambiguous $\ldots \ldots \ldots \ldots \ldots$ "So many innocent lives have been taken."

4. Both Americans and Vietnamese explicitly mentioned; objec-

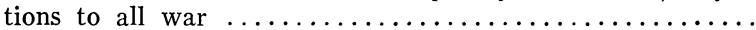
"I hate violence." "Too many Americans and Vietnamese killed."

5. Vietnamese killed or injured (includes references to any Vietnamese, on either side, either civilian or soldier) $\ldots \ldots \ldots \ldots$. "Thousands of Vietnamese killed by the mass bombing."

6. Vietnamese people hurt in other ways $\ldots \ldots \ldots \ldots \ldots \ldots \ldots$ "We make racketeers out of the people and prostitutes out of the women."

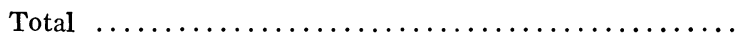

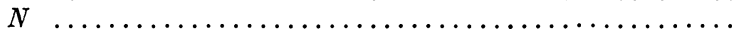

III. Loss of U.S. Resources:

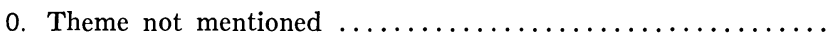

1. U.S. resources wasted: no mention of alternative social uses ... "It's ruined our economy."

2. U.S. resources wasted: explicit mention of alternative social uses "We send money there and there's poverty here."

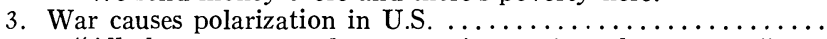
"All the young people are turning against the country."

4. We have enough problems of our own to take care of (vague;

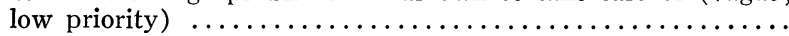
"Enough problems here at home."

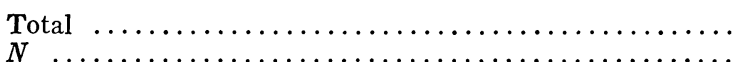

VII. Vietnam War Is Internal Conflict

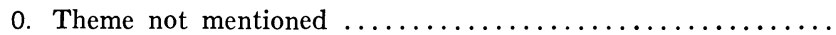

1. It is a civil war (codes only clear references to civil war) $\ldots$. 
TABLE 1 (Continued)

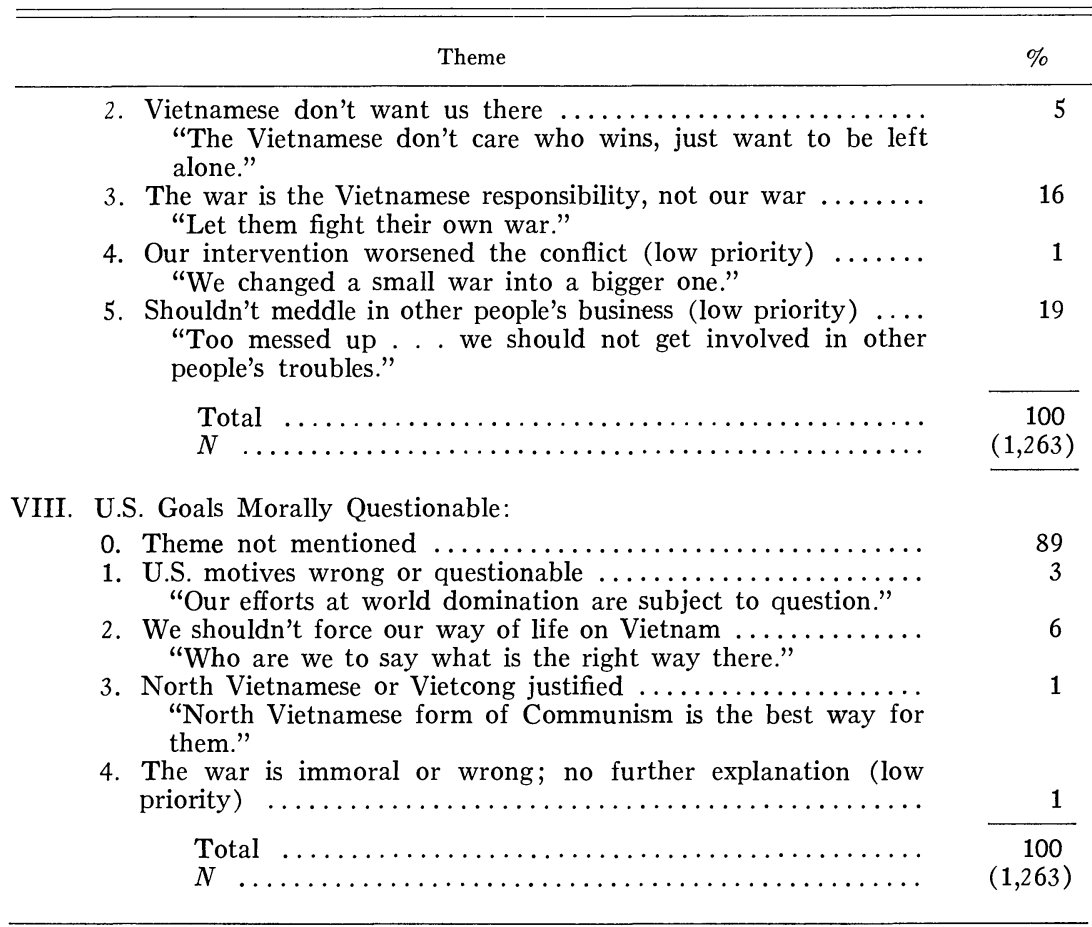

Detroit sample. ${ }^{11}$ The themes were not mutually exclusive; hence a response could be coded other than zero on as many of the 10 themes as were appropriate, although within a given theme a response could be coded in one subcategory only.

The Detroit marginal percentages in table 1 can be inspected in light of the theoretical expectations developed earlier in this paper. Content analysis of speeches and writings by antiwar protest leaders would also be useful as a basis for comparison. For our present purposes, however, we will make use of responses to the same closed and open questions by students in three sociology classes at the University of Michigan: an intro-

11 The remaining five themes, and percentage coded as mentioning each, were: IV. Vietnam Not Important to American Interests, $28 \%$; V. Okay to Intervene, But Handling of War Incorrect, 15\%; VI. Entry into War Not Procedurally Correct, 15\%; IX. The War Is Confusing, $11 \%$; X. Problems with South Vietnamese Government or People, $6 \%$. In general, these themes tend either to duplicate or to provide additional support for the results presented in the text. A copy of the complete set of coding instructions for all 10 themes, together with the results of check coding, can be obtained from the Detroit Area Study. Coding was carried out by professional Survey Research Center coders. 
ductory class consisting almost entirely of freshmen; the same course but with a majority of sophomores; and a more advanced concentration course for juniors. The combined sample (initial $N=278$, reduced to 236 who answered "yes" to the closed question), while obviously not an adequate representation of the university, provides a useful contrast, as we will see. In one sense it is too conservative a sample, since it seriously underrepresents juniors, seniors, and graduate students who have been most fully exposed to the prevailing university views on the war. ${ }^{12}$ Exactness is not absolutely essential here because we use the sample mainly to bring out broad differences between the general population and at least a core of students at the university. It can safely be assumed that the students and faculty members who actually engage in antiwar protests would show more sharply the same trends as our classroom samples.

It would be misleading to proceed as though the open-ended responses and code summaries can provide a definitive, completely objective, or simple test of the moral-pragmatic distinction I have proposed. Instead we will use the data in table 1 on an exploratory basis both to evaluate important aspects of that distinction and to illuminate public thinking about the war. Let us begin with the evaluative emphasis, looking at the themes that provide an indication of the degree of moral concern about the war in the general (Detroit) population. The results for the student and Detroit samples on the three most relevant themes are summarized in table $2 .{ }^{13}$

12 All the variables reported below that have been examined within the student sample show an accentuated difference for the more advanced classes. This is also reflected in answers to the initial "mistake" question: $85 \%$ of the freshman class regard the war as a mistake, $88 \%$ of the mainly sophomore class, and $98 \%$ of the junior class. On Theme VIII, the percentages offering moral criticisms of the United States are $22 \%, 38 \%$, and $49 \%$, respectively, for the three classes.

13 Student responses were coded nonzero on an average (mean) of 3.0 themes, as against an average of 2.3 for the Detroit sample. By multiplying the Detroit nonzero percentages by 1.3 , they can be adjusted upward to a level that "corrects" for this difference in total nonzero responses. The correction is relevant only where the zero category is included in a comparison (table $2 \mathrm{~B}$ below, but not $2 \mathrm{C}$ or $2 \mathrm{~A}$ ), and even then has only minor effects on our results. Since the correction itself involves some questionable assumptions and other problems, our tabled data are in their original form. However, "corrected data" were looked at, and $\chi^{2}$ 's calculated on the basis of such data, in all relevant cases below; in none did an appreciable change result, as indeed is evident from the very large size of most of the $\chi^{2}$ statistics presented below. We should also note that the student responses differ in several other ways from the Detroit interviews. They were obtained at the beginning of 1972 , in self-administered form in classrooms, without the context of other questions, and at the request of a faculty member (rather than a more neutral interviewer). It is doubtful that any of these differences affected the content of the responses seriously, though the differences may account for the greater quantity. We will see below that the main Detroit vs. student differences are replicated to a significant degree within the Detroit sample when younger college-educated respondents are singled out for attention. Other checks on the results will also be presented. 
TABLE 2

Comparisons of General (Detroit) and Student Samples on Three Themes

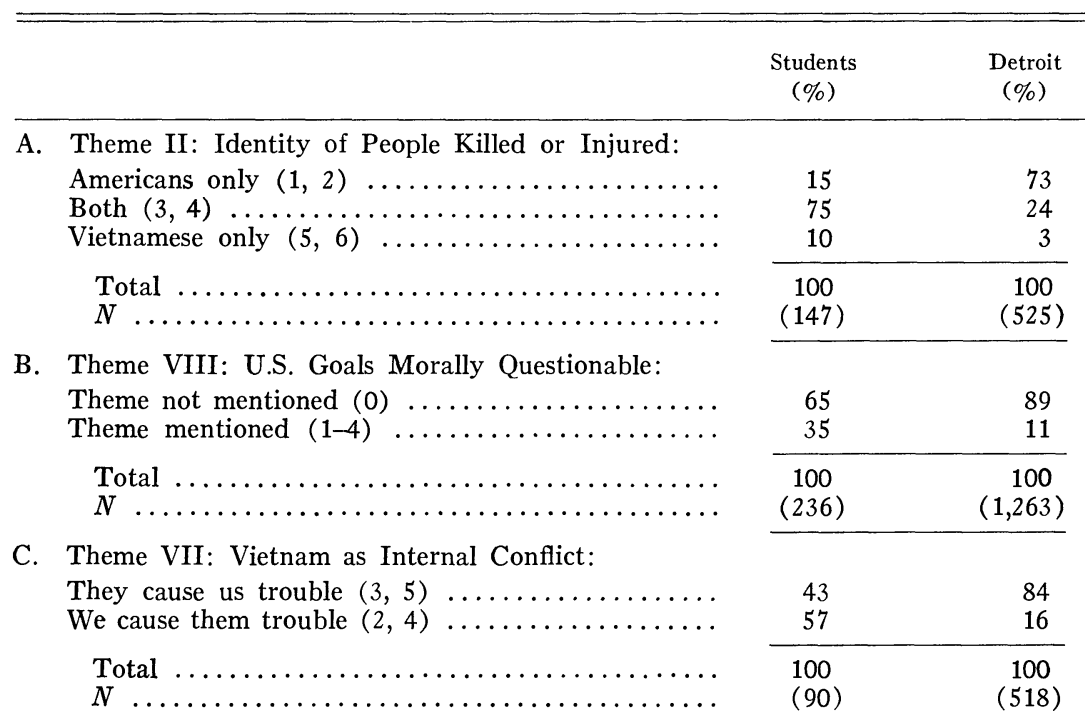

Note.-For full description of themes, see table 1. Note that $\mathrm{A}$ and $\mathrm{C}$ here are based only on those who mention a particular theme, while B compares those who mention a theme and those who do not. All three panels show relationships statistically significant at $P<.001$, using $\chi^{2}$ and 3 , 2, and $2 \mathrm{df}$, respectively.

\section{COMPARISONS OF GENERAL POPULATION AND STUDENTS}

Theme II, People Killed or Injured by the War, is one of the two most frequently mentioned by both samples, perhaps partly because of the wording of the original closed question, but even more likely because of the salience of the theme to any question about the war. Students show this concern to a greater degree than does the general public $(62 \%-42 \%$, $\chi^{2}=34.6,1 \mathrm{df}, P<.001$ ), but the more important differences have to do with the types of mention, as shown in table $2 \mathrm{~A}$. A primary focus of the college-related antiwar movement has been on the destruction wrought on Vietnam and the Vietnamese by American military technology. Even those moral critics of the war who grant some legitimacy to American political goals argue that the costs to the Vietnamese have long since exceeded any possible gain to them. From this standpoint, the American military effort is well symbolized by a U.S. officer's explanation at Ben Tre during Tet in 1968: "It became necessary to destroy the town to save it" (Oberdorfer 1971, p. 184). Our research question, then, is the extent to which concern for Vietnamese suffering shows up in the answers of those members of the general public who oppose the war. We see in table $2 \mathrm{~A}$ that, of those Detroit respondents who oppose the war and who mention lives 
lost or injured as a reason for their opposition, nearly three-quarters refer only to American soldiers. The students, on the other hand, are much more likely to refer to both Americans and Vietnamese and also more likely to refer to Vietnamese only. Again we must note that even the students reflect only imperfectly the emphasis of the humanitarian part of the antiwar movement. But they reflect it to a much greater degree than does the general public.

Theme VIII covers a more political type of antiwar criticism, one which centers not on the destructive nature of the war, but rather on the motivations for, and goals of, American policy in Vietnam. The category includes accusations of imperialism, support for the North Vietnamese, and more general criticisms of the war as "immoral." We would not expect anything approaching consensus on this among students, but in fact more than a third do touch on such a theme, as shown in table 2B. In the Detroit sample, however, only one out of nine persons gave a response classified anywhere under this theme. For the general public, opposition to the war seldom entails a political-moral criticism of American goals in Vietnam.

Theme VII provides a more subtle distinction between moral and pragmatic concerns. The theme as a whole deals with emphasis on the Vietnam war as an internal conflict, but there are two ways of looking at this. The one represented by categories 3 and 5 focuses on our staying out of "their troubles." "Let them fight their own wars" is the epitome of this outlook. The other point of view, categories 2 and 4, carries the assumption that either the Vietnamese do not want American involvement or such involvement only makes the war worse for Vietnam. (Category 1, "civil war," probably belongs with the second point of view, but we omit it as somewhat ambiguous.) In other words, the first perspective on the war is strictly in terms of American interests and concludes that "they cause us trouble"; the second perspective is at least partly in terms of Vietnamese interests and concludes that "we cause them trouble." Summarized under these rubrics, table $2 \mathrm{C}$ shows that Detroiters who mention this theme at all do so overwhelmingly in terms of "they cause us trouble." Students, however, are much more likely to place the emphasis on "we cause them trouble."

Thus on all three of these themes we find sharp differences between the general population and the student sample. If we are correct that a sample of students who actually participate in antiwar demonstrations would be still more different from the Detroit population, we begin to get some measure of the gap between the campus-based protests and the public disenchantment with the war reflected in national surveys. It is interesting that this gap itself is validated in a sense by our code, as can be seen from Theme III, category 3: "War causes polarization in U.S." This category is mentioned infrequently by the general population $(4 \%)$, but $16 \%$ of the students refer to the fact that the war has created polarization within 
America. ${ }^{14}$ Perhaps for much of the Detroit population polarization is not salient because protesters are perceived as deviants rather than dissenters. Students, on the other hand, personally experience the conflict between the university climate of opinion and that in their homes or hometowns.

Some modifications in the moral-pragmatic distinction are required by findings on other themes. Theme I, U.S. Not Winning the War, represents the pragmatic position in perhaps its purest form, namely, that the war is a mistake because we are not winning it, cannot win it, or have not tried to win it (see table 1). ${ }^{15}$ Approximately a third of the Detroit respondents give this response, three times more than offer a specifically moral critique (Theme VIII), it is true, but still far less than unanimity. Moreover, $29 \%$ of the students are also coded in Theme I categories, indicating that students are nearly as likely to give such a pragmatic response as are members of the general population. It is probable that this is the case generally: what are distinctive are moral types of responses, while pragmatic reasons are given by all groups who oppose the war. Only when the two positions are incompatible within a particular theme will students and the general population differ greatly. One other theme given frequently by both students and general public is Theme IV-4: "We gain nothing from the war" (not shown in a table). This is coded for $20 \%$ of the students and for $22 \%$ of the Detroit sample, and indicates the general lack of clarity about American aims and purposes in Vietnam. Finally, an unexpected finding occurs with Theme X-1: "Negative characteristics of South Vietnamese government" (not shown in a table). We had expected this to be mentioned with some frequency by the general population, since it is often referred to in the mass media, but in fact it is hardly mentioned at all $(3 \%)$. Students are significantly more likely to focus on negative characteristics of the South Vietnam government $(10 \%)$, suggesting that this complaint about our involvement tends to appeal mainly to those influenced by a general political-moral criticism of the war.

14 This category against all others (including zero) yields a $\chi^{2}$ of $49.8,1 \mathrm{df}, P<.001$, for students vs. Detroit. Unlike the comparisons in table 2 , this comparison is strictly post factum, but its significance is so high as to make replicability likely.

15 The subthemes obviously differ greatly both in their sophistication and in their implications for action. "The war is unwinnable" includes the type of judgment finally made by those Pentagon officials and advisers who, having first participated in the escalation of the war, later sought to deescalate it (see Hoopes 1969). "We are not trying to win the war," on the other hand, is a pure hawkish response identified with the military's push for more extreme bombing and related measures. The remaining two categories suggest less a policy point of view than a matter-of-fact if weary observation. Despite these important differences, all four categories must be described as pragmatic in terms of our present frame of reference. 
The Detroit sample can be further broken down in several useful ways. As was mentioned earlier, public opposition to the war in surveys over the past seven years has been associated with lower education and to some extent with older age. Opposition has also been more characteristic of women than of men by a small degree, and of blacks than of whites by a substantial margin. As table 3 shows, both the Gallup national data of

TABLE 3

Percentage Believing the United States Made a Mistake in Sending Troops to Vietnam, by Sex, Race, Education, and Age

\begin{tabular}{|c|c|c|}
\hline & $\begin{array}{l}\text { Gallup National } \\
\text { Results (May 1971) } \\
\quad(N=1,500+)\end{array}$ & $\begin{array}{l}\text { Detroit Area Study Results } \\
\text { (April-August 1971) } \\
(N=1,881)\end{array}$ \\
\hline \multicolumn{3}{|l|}{ Sex: } \\
\hline Male $\ldots \ldots \ldots \ldots \ldots \ldots \ldots \ldots$ & 65 & 66 \\
\hline Female $\ldots \ldots \ldots \ldots \ldots \ldots$. & 72 & 72 \\
\hline \multicolumn{3}{|l|}{ Race: } \\
\hline White $\ldots \ldots \ldots \ldots \ldots \ldots$ & 67 & 68 \\
\hline Black* ............... & 83 & 82 \\
\hline \multicolumn{3}{|l|}{ Education: } \\
\hline College $\ldots \ldots \ldots \ldots \ldots \ldots$ & 66 & 70 \\
\hline High school $\ldots \ldots \ldots \ldots \ldots \ldots$ & 67 & 68 \\
\hline Grade school $\ldots \ldots \ldots \ldots \ldots \ldots$ & 75 & 73 \\
\hline \multicolumn{3}{|l|}{ Age: } \\
\hline $21-29 \quad \ldots \ldots \ldots \ldots \ldots \ldots \ldots$ & 63 & 68 \\
\hline $30-49 \quad \ldots \ldots \ldots \ldots \ldots \ldots \ldots$ & 67 & 66 \\
\hline 50 and over $\ldots \ldots \ldots \ldots \ldots$ & 73 & 74 \\
\hline Total $\ldots \ldots \ldots \ldots \ldots \ldots$ & 68 & 69 \\
\hline
\end{tabular}

NotE.-Percentages calculated after removing missing data (11\% reported by Gallup, $3.3 \%$ by Detroit Area Study).

* Includes other nonwhites for Gallup only.

May 1971 and our Detroit sample of summer 1971 continue to display these sex and race relationships with almost identical percentages. Gallup also shows small but clear age and education relationships, while our Detroit sample reveals less consistent associations for both these variables. ${ }^{16}$ In any case, it is useful to know how all four of these basic back-

16 When race is controlled, the Detroit sample reveals the same relationship to age for whites that Gallup reports for the nation as a whole. This is a reasonable control, since the percentage of blacks in our Detroit sample is twice that at the national level and therefore prevents an exact comparison. (From this the reader will infer correctly that the relationship of age to opposition to the war is reversed for blacks: younger blacks in the Detroit sample are more likely than older blacks to regard our intervention as a mistake.) However, with or without the control for race, we do not obtain for Detroit the usual (or any other) association between support of the war and education. 
ground characteristics relate to reasons for being against the war. ${ }^{17}$ At least three, it may be noted, identify groups excluded from political dominance: blacks, women, and low-educated persons.

Let us begin with education and age, two variables that are usefully treated together, and with the focus on the white subsample where the number of cases is large enough to allow for more detailed analysis. The main findings here, as shown in table 4 , fit well with those reported earlier

TABLE 4

A. Percentage Mentioning U.S. Motives Morally Questionable (Theme VIII) by Education and Age

\begin{tabular}{|c|c|c|c|c|c|c|}
\hline \multirow{2}{*}{\multicolumn{2}{|c|}{ AGE }} & \multicolumn{5}{|c|}{ EDUCATION } \\
\hline & & $0-8$ & $9-11$ & 12 & $13-15$ & $16+$ \\
\hline $\begin{array}{l}21-29 \\
30-49 \\
50+\end{array}$ & $\begin{array}{l}\ldots \\
\ldots \\
\ldots \ldots\end{array}$ & $\begin{array}{l}\ldots(5) \\
0(21) \\
8(90)\end{array}$ & $\begin{array}{l}4(28) \\
4(75) \\
5(100)\end{array}$ & $\begin{array}{r}3(67) \\
8(147) \\
12(89)\end{array}$ & $\begin{array}{l}12(49) \\
17(76) \\
13(47)\end{array}$ & $\begin{array}{l}28(36) \\
24(66) \\
21(38)\end{array}$ \\
\hline
\end{tabular}

B. Percentage Mentiontng American Soldiers Killed or Injured (II-1, 2) by Education and Age

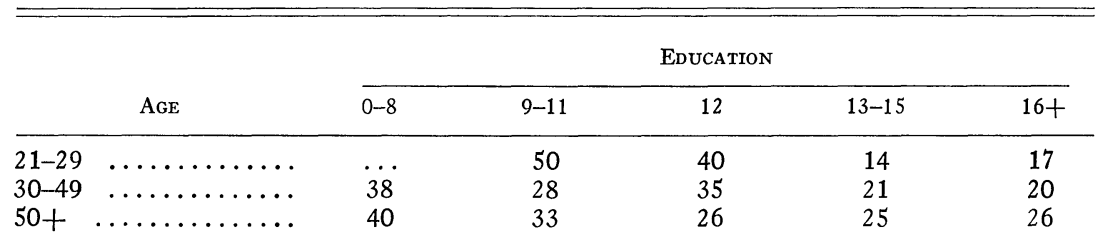

NotE.-Results are for whites only. The figures in parentheses indicate the base $N$ on which each percentage is based. The same bases apply in both panels of the table. The cells based on only five cases are omitted as unstable; the frequencies are zero in $\mathrm{A}$ and one in $\mathrm{B}$.

for students versus the general population. For example, Theme VIII, U.S. Goals Morally Questionable, produces a strong positive relationship to education, with a quarter of the college graduates voicing some moral criticisms of U.S. motives or actions, but decreasing proportions doing so at lower educational levels. Age may act as a conditional factor here, with the gap in mention of this moral theme somewhat greater between high and low educated for the young than for the old. That is, among young people 21-29 who oppose the war, those with college education are fairly

17 There are slight differences in the average number of codable (nonzero) responses given by different population subgroups. At the extreme, those with grade school education (0-8) give an average of 2.16 nonzero responses; those with some college $(13+)$ give an average of 2.44 nonzero responses-a ratio of only 1.1. This difference is too slight to affect the results presented below. Black-white, male-female and age differences are even smaller on this response count. 
likely to do so in terms morally critical of government actions, while those with less than high school education are very unlikely to do so. Complementing this, we find that on Theme II, People Killed or Injured, those young opponents of the war without college education are considerably more likely to mention American soldiers being killed or injured (and less likely to mention Vietnamese) than are those with at least some college training-perhaps reflecting the fact that there is not only a social class difference in sensitivity to moral issues but also a social class difference among young men in the risk of entering the army and being sent into combat. These data support our earlier finding of a gulf between college students and the general population in their reasons for opposing the war, and also reinforce the point sometimes made that the gulf is not only between young and old but between those young people with college education and those without it. ${ }^{18} \mathrm{We}$ are also reminded that moral reasons for opposing the war (as well as principled support for it) may be easier to elaborate when one is not directly in the line of fire.

The less educated, therefore, and especially less educated youth, are particularly likely to interpret their opposition to the war in terms of the danger to American lives. Since older Americans tend to be low in education, this also helps explain the special opposition to the war of older people. However, age as such is associated with still another type of opposition, labeled earlier as "they cause us trouble" (Theme VII-3, 5). This

18 The methods developed by Goodman $(1969,1972)$ for analysis of multivariate contingency tables were applied to the results in table 4B. For full table (including the five cases omitted in percentaging), only the relationship between education and mention of American soldiers is significant $\left(\chi^{2}=21.2,4 \mathrm{df}, P<.001\right.$; with age partialed out, $\left.\chi^{2}=32.5,4 \mathrm{df}, P<.001\right)$. Age is not significantly related to mention of American soldiers $\left(\chi^{2}=0.8,2 \mathrm{df}\right)$, nor is there a significant three-way interaction $\left(\chi^{2}=11.6,8 \mathrm{df}, P>.10\right)$. However, since the interaction expected on the basis of our earlier student versus Detroit findings was specified in terms of young college-educated persons, the problem was run again with age and education each reduced to two categories. The table below presents the observed percentages on the basis of this specification, along with, in brackets, those expected on the hypothesis of no three-way interaction. (The appropriate base $N$ 's can be constructed from table 4.)

\begin{tabular}{ccc}
\hline \multirow{2}{*}{ AGE } & \multicolumn{2}{c}{ Education } \\
\cline { 2 - 4 } & $0-12$ & 13 and Over \\
\hline $21-29 \ldots \ldots \ldots \ldots \ldots \ldots$ & $42[36]$ & $15[22]$ \\
30 and over $\ldots \ldots \ldots \ldots$ & $33[34]$ & $22[20]$ \\
\hline
\end{tabular}

The predicted interaction does occur $\left(\chi^{2}=4.7,1 \mathrm{df}, P<.03\right.$ for rejection of twovariable model). The largest discrepancies between observed and expected frequencies of mention of American soldiers are located among those 21-29 years old, indicating that the young college-educated differ not only from the rest of the population generally but especially from the noncollege portion of their own cohort. I am indebted to Otis Dudley Duncan for pointing out to me the particular relevance of Goodman's approach for this problem; Davis's (1972) exposition also proved helpful. 
stance should perhaps be relabeled "traditional isolationism," for it focuses on the avoidance of intervention into troubles elsewhere. The percentage giving this response is directly associated with age, but in a single-step threshold fashion:

\begin{tabular}{cccccc}
\hline \multicolumn{8}{c}{ Age IN Decades } \\
\hline $29-29$ & $30-39$ & $40-49$ & $50-59$ & $60-69$ & 70 and Over \\
\hline 32 & 29 & 31 & 42 & 40 & 42 \\
\hline
\end{tabular}

Those over 50 are a third again as likely as younger persons to voice this sentiment, but there is little variation within either of the age categories created by the division at 50 . The relationship continues to hold when education is controlled, except that the rejection of isolationism is strongest in the 30-49 age range. This is exactly the generation that came to maturity between the beginning of World War II and the beginning of serious frustration over Vietnam - that is, the generation most exposed to what might be called successful "military internationalism" on the part of the United States. Presumably it is this age group that finds especially resonant administration appeals referring to "Munich" and to the early episodes of the Cold War. In any case, whether or not this generational interpretation is correct, we see that the older age groups that have been disproportionately opposed to the war have often been drawn to that position on the basis of traditional isolationist sentiments. We assume that the failures of intervention in Vietnam have reinforced these sentiments, although we lack trend data to demonstrate such reinforcement. ${ }^{19}$

The persistence of both sex and race differences in poll data on the war over the last seven years has been interpreted as evidence that at least two groups-blacks and women-have special reasons for their opposition. It is easy to hypothesize that these reasons fit under the several categories that operationalize moral reservations or criticisms. In the case of women this could involve a less aggressive and greater humanitarian attitude. Black opposition, on the other hand, could reflect disenchantment with American society generally and therefore a greater willingness to criticize the war in moral or ideological terms. We find some support for both these expectations in our thematic data, but important qualifications are needed as well.

Considering sex differences first, table 5 shows that women are more

19 One other result involving education that is worth noting is a positive association between number of years of schooling and belief that the war is "unwinnable" (I-1). Percentages coded into the latter category are: 4\% (grade school), $7 \%$ (some high school), $10 \%$ (high school graduates), 15\% (some college or above). The finding supports our earlier note about the sophistication of this point of view. The association involves only education and not age. 
TABLE 5

Percentages by Sex on Selected Antiwar Themes and Subthemes

\begin{tabular}{|c|c|c|c|}
\hline & $\begin{array}{c}\text { Men } \\
(N=535)\end{array}$ & $\begin{array}{c}\text { Women } \\
(N=728)\end{array}$ & Difference \\
\hline \multicolumn{4}{|l|}{ Theme I: U.S. Not Winning War } \\
\hline $\begin{array}{l}\text { We are not trying to win the war }(2) \ldots \ldots \ldots \\
\text { The war is not ending }(4) \ldots \ldots \ldots \ldots \ldots\end{array}$ & $\begin{array}{l}11 \\
13\end{array}$ & $\begin{array}{r}5 \\
18\end{array}$ & $\begin{array}{r}6^{*} \\
-5^{*}\end{array}$ \\
\hline $\begin{array}{c}\text { Theme II: People Killed or Injured } \ldots \ldots \ldots \ldots \ldots \\
\text { Americans only }(1 \text { and } 2) \ldots \ldots \ldots \ldots \ldots \ldots \ldots \ldots \\
\text { Both }(3 \text { and } 4) \quad \ldots \ldots \ldots \ldots \ldots \ldots \ldots \ldots \\
\text { Vietnamese only }(5 \text { and } 6) \ldots \ldots \ldots \ldots \ldots\end{array}$ & $\begin{array}{r}33 \\
22 \\
9 \\
2\end{array}$ & $\begin{array}{r}48 \\
37 \\
10 \\
1\end{array}$ & $\begin{array}{l}-15^{* *} \\
-15 \\
\mathbf{a} \\
\mathrm{a}\end{array}$ \\
\hline Theme VIII: U.S. Goals Morally Questionable .. & 15 & 7 & $8^{* *}$ \\
\hline
\end{tabular}

a Less than $2 \%$ difference.

${ }^{*} P<.05$, using $\chi^{2}$ for category $\mathrm{I}-2$ versus remainder of Theme $\mathrm{I}(\mathrm{df}=1) . P<.01$ for category I-4 versus remainder of Theme I $(\mathrm{df}=1)$.

**P $P<.001$, using $\chi^{2}$ for zero versus nonzero categories $(\mathrm{df}=1)$.

likely than men to mention "People killed or injured" as a reason for opposing the war, but that this difference is entirely accounted for by the "Americans only" category. Men and women do not differ at all with regard to mention of Vietnamese deaths or suffering. Thus the greater concern of women for the pain of war seems to be channeled wholly along national lines. On other themes, our general finding is that men are more critical of the war effort in all ways, both moral and pragmatic. Men are more likely to complain that "we are not really trying to win the war"-a "hawk" type of response-but men are also more likely than women to question the morality of U.S. motives and actions in Vietnam. ${ }^{20}$ Women are more apt to phrase their opposition in more passive ways, for example, that "the war goes on and on" (I-4). These findings help explain why the sex difference in opposition to the war has never seemed to translate well into political actions. Despite their concern for American lives lost in war, Detroit women are less rather than more critical of the policies that support and guide the war effort.

The black-white difference on the basic "mistake" question is the largest in table 3 , and this finding of greater black opposition has held consistently over the course of attitude surveys on the war. Moreover, a number of student responses, self-identified as black, offer criticisms of the war in clear racial terms: that the war is racist and genocidal, that the money should be spent at home on urban problems, etc. Despite this indirect evidence that blacks may be ideologically more opposed to the war than whites, the Detroit black sample of adults gives only a little evidence

20 These conclusions are not changed when age and education are controlled. For example, considering only the youngest and most educated respondents-those 21-29 with 13 or more years of school- $26 \%$ of the 53 men question U.S. motives or actions (Theme VIII), as against only $6 \%$ of the 32 women. 
TABLE 6

Percentages by Race on Selected Antiwar Themes and Subthemes

\begin{tabular}{|c|c|c|c|}
\hline & $\begin{array}{c}\text { Black } \\
(N=322)\end{array}$ & $\begin{array}{c}\text { White } \\
(N=941)\end{array}$ & Difference \\
\hline Theme I: U.S. Not Winning War (1-4) $\ldots \ldots$ & 20 & 39 & $-19 *$ \\
\hline $\begin{array}{l}\text { Theme II: People Killed or Injured } \ldots \ldots \ldots \ldots \\
\text { Americans only }(1 \text { and } 2) \ldots \ldots \ldots \ldots \ldots \ldots \ldots \\
\text { Both }(3 \text { and } 4) \text {. } \ldots \ldots \ldots \ldots \ldots \ldots \ldots \ldots\end{array}$ & $\begin{array}{r}42 \\
31 \\
10 \\
1\end{array}$ & $\begin{array}{r}42 \\
30 \\
10 \\
2\end{array}$ & $\begin{array}{l}\mathrm{a} \\
\mathrm{a} \\
\mathrm{a} \\
\mathrm{a}\end{array}$ \\
\hline $\begin{array}{l}\text { Theme III: Loss of U.S. Resources } \ldots \ldots \ldots \ldots \\
\text { Explicit mention of alternative uses }(2) \ldots \ldots\end{array}$ & $\begin{array}{r}22 \\
4\end{array}$ & $\begin{array}{r}20 \\
3\end{array}$ & $\begin{array}{l}\mathrm{a} \\
\mathrm{a}\end{array}$ \\
\hline $\begin{array}{l}\text { Theme VII: Vietnam War Is Internal Conflict } \\
\text { They cause us trouble }(3 \text { and } 5) \ldots \ldots \ldots \ldots \\
\text { We cause them trouble }(2 \text { and } 4) \ldots \ldots \ldots \ldots\end{array}$ & $\begin{array}{r}52 \\
42 \\
5\end{array}$ & $\begin{array}{r}44 \\
32 \\
7\end{array}$ & $\begin{array}{c}6 \\
10^{*} \\
\mathbf{a}\end{array}$ \\
\hline Theme VIII: U.S. Goals Morally Questionable .. & 10 & 11 & a \\
\hline Theme IX: The War Is Confusing ( 1 and 2$) \ldots$ & 18 & 6 & $12 *$ \\
\hline
\end{tabular}

a Less than $2 \%$ difference. case).

of being more highly motivated by moral sentiments than are whites. As table 6 shows, blacks as a group do not differ from whites in their distribution of responses to Theme II, People Killed or Injured, or to Theme VIII, U.S. Goals Morally Questionable. They also do not differ significantly on a theme (III-2) which concerns alternative social uses of money and resources now being spent in Vietnam, although this is a point often made by black leaders. Blacks do differ, however, quite substantially on Theme I, U.S. Not Winning War, with $19 \%$ fewer responses here than reported by whites, the reduction being distributed evenly over categories 1, 2, and 4. In other words, blacks are much less concerned than whites about the lack of "victory" in Vietnam, and therefore in this sense black opposition to the war seems less pragmatically based than is the case for whites. But this deemphasis on pragmatic opposition does not appear to be translated into a more positive critique of the war. The $19 \%$ difference on Theme $I$ is not compensated for elsewhere in any single category; it generally appears to be reversed in the categories we have called, "They cause us trouble" (Theme VII-3, 5), as well as on other categories indicating confusion over what the war is about (especially Theme IX). Together these findings suggest a picture of the war as a distant and unclear set of troubles belonging to someone else-an isolationist trend of thinking based on low interest in the war, rather than on conscious moral opposition to it. ${ }^{21}$

21 Detailed internal analysis of the black sample is difficult because of the small number of cases. However, certain findings can be noted. On the initial "mistake" question, 
When the evidence from both past opinion surveys on Vietnam and the present Detroit study is drawn together, the broad distinction between

blacks at all age and educational levels are more apt than comparable whites to consider intervention to have been a mistake; however, the differences are greatest .among persons in their twenties regardless of education. This may suggest that younger blacks have a distinctive set of reasons for opposing the war, but in fact nothing of this sort emerges. On the contrary, we do find that older and less educated blacks report more "confusion" about the war (Theme IX) than do comparable whites, but there are no uniquely emphasized reasons given by younger blacks in our sample. In sum, we are able to "explain" the greater opposition to the war among both older and less educated blacks, but there seem not to be equally salient patterns among younger, more educated blacks that distinguish them from comparable whites. The clearest trend is for young college-educated blacks to mention the waste of money in Vietnam (III-1), but this is a very small subsample $(N=19)$ and the import of the response is not clear; Theme III-2, dealing with alternative uses for the money at home, is not emphasized. When sex is controlled, differences emerge for blacks similar to those for whites. Unfortunately we are not able to control age, education, and sex simultaneously within a cross-tabular framework allowing a search for interaction. It is also possible that black responses are being obscured by race-of-interviewer effects (Hyman 1954; Schuman and Converse 1971). Our sample design included a systematic variation by race of interviewer, and we do find that black respondents are significantly $(P<.05)$ more likely to question U.S. goals (Theme VIII) when being interviewed by blacks $(13 \%)$ than by whites $(6 \%)$. The association is not strong, however, and even if we substitute the higher percentage $(13 \%)$ into table 6 , the difference between blacks and whites on this theme remains trivial. No other themes show significant differences by race of interviewer; there are some trends that are of theoretical interest (the largest involving greater use to black interviewers of Theme IV-4: "We gain nothing from the war"), but again they are too slight to change the basic picture presented in table 6. Moreover, a special recoding of a subsample of 110 black responses to uncover subtle racial references possibly unnoticed in our thematic analysis produced only one such reference. One final piece of information that is suggestive in interpreting the racial differences comes from an additional coding of the open Vietnam responses. When respondents referred to the U.S. government indirectly by use of a pronoun, we coded whether the pronoun chosen was "we" or "they." Blacks are considerably less likely to use "we" and more likely to use "they" than are whites:

\begin{tabular}{lccc}
\hline \hline & & Blacks & Whites \\
\hline "We" $\ldots \ldots \ldots \ldots \ldots \ldots \ldots$ & $59 \%$ & $85 \%$ \\
"They" $\ldots \ldots \ldots \ldots \ldots$ & $41 \%$ & $15 \%$ \\
\cline { 3 - 4 } & & $100 \%$ & $100 \%$ \\
& & $(219)$ & $(709)$ \\
\hline
\end{tabular}

Note. $-\chi^{2}=67.9, \mathrm{df}=1, P<.001$.

This racial difference holds up well when age and education are simultaneously controlled (mean racial difference over nine categories: $22 \%$ ). However, it is greatest among young, well educated blacks; indeed, use of "we" generally increases with increased education among both blacks and whites, except among blacks 21-29, where the direction is reversed. The exact meaning of these findings is not entirely clear, but they probably signify a sense of distance from the exercise of governmental power on the part of blacks, though how much of this is passive and unconscious, as against actively alienated, remains to be determined. 
moral and pragmatic types of opposition to the war remains a persuasive one. The college-based protest has been led almost entirely by spokesmen presenting the moral critique, but much of the public opposition to the war flows from quite different sources. These have to do primarily with the long and frustrating nature of the war but also draw on other closely related themes, of which the two most important are probably the costs in American lives and the lack of clarity about the goals of the war. A very pragmatic current of isolationism is also involved, symbolized by the phrase: "Let them fight their own war.",22

The moral-pragmatic distinction does not, of course, correspond exactly to the difference between major universities and the rest of the population. One will find both types of opposition in both settings-though, as we have shown, their proportions differ sharply. Nor is it necessary or wise to assume that the distinction represents characterological differences between the campus and the city. We are dealing here with ideology, not with personality. While it is probably true that some of the leaders and participants in the college-based protest movement are motivated by deeply held ethical principles, it would obviously be a mistake to infer individual character directly from verbal reasons for opposition to the war. College students provide moral criticisms primarily because they are exposed to, and learn, such criticisms on campus. In addition, they are intellectually equipped to elaborate their sense of dissatisfaction with the war, and to turn personal concern about participating in it into a critical examination of its goals-what Weber meant by rationalization, which is far more than merely "explaining away" something distasteful. Our aim here has been an analysis of the content and social bases of antiwar sentiments and ideology, not an attempt at delineation of personality differences.

From a policy standpoint, the main overall implication of our argument is that the president has never had much to fear directly from the college antiwar movement, because the latter does not speak the same language

22 One must expect emphases to change somewhat over time as the impact of the war itself changes. Several months after our main field interviewing, we conducted brief telephone reinterviews with a random subsample of 198 respondents. Nine of the 10 themes showed a drop in mention, perhaps merely a function of the telephone context, but one showed a rise. This was Theme VII: Vietnam as an Internal Conflict, and especially the subthemes ( 3 and 5) we have labeled "they cause us trouble" or traditional isolationism, which increased from $32 \%$ to $46 \%$ for the relevant reinterview subsample $(N=119)$. The largest single drop in mention (from $42 \%$ to $27 \%$ ) occurred for Theme II: People Killed or Injured. Since the salience of the war itself was decreasing at that point (for example, U.S. casualties had declined to a relatively tiny number), it makes sense that such specific objections were disappearing and being replaced by a hardening of general isolationist sentiment toward a more and more remote "nuisance." These findings reinforce the value of the broad abstractions "moral" and "pragmatic"; the distinction carries the danger of oversimplification, but it also points to more enduring stances toward the war than do most of the specific themes and subthemes. 
as the general public. Public disillusionment with the war has grown despite the campus demonstrations, not because of them. The president's primary enemy is and always has been the Viet Cong and the North Vietnamese, for it is their resilience and success that undermine larger public support for the war. The antiwar movement is not wholly ineffective: it influences commentators and columnists, who in turn (but in different words) influence the public. And it provides energy and money in political campaigns. But attempts by moral spokesmen against the war to proselytize the general public directly are likely to fail or even prove counterproductive unless carried out with more skill and less righteousness.

There is another long-term implication to the moral-pragmatic distinction. Our Detroit questionnaire included a question on a possible future Communist-inspired revolution in South America (preceding the Vietnam question by several items). As might be expected, those who regard the present Vietnam war as a mistake are more likely to resist intervening in such a future situation. But our thematic code proves useful in distinguishing further. Of those who are opposed to the Vietnam intervention simply because we are not winning (Theme I), 50\% would still intervene in a new South American war. But of those who criticize the Vietnam war on moral grounds (Theme VIII), only $25 \%$ would intervene in a new war. The reasons people give for thinking the Vietnam war a mistake are linked to their willingness to become involved in future wars of the same general type. We need not pretend to be entirely clear on cause and effect here, but we can insist on the value of understanding more thoroughly not only pro and con positions, but the reasons for them.

\section{REFERENCES}

Converse, Philip E., and Howard Schuman. 1970. Scientific American 222 (June): $17-25$.

Davis, James A. 1970. "American Opinion on the Vietnam War: March, 1966-March, 1970." Multilith.

12. 1972. "The Goodman System for Significance Tests in Multivariate Contingency Tables." National Opinion Research Center, University of Chicago.

Gallup Opinion Index. 1965-current. Princeton, N.J.: International.

Goodman, Leo. A. 1969. "On Partitioning $\chi^{2}$ and Detecting Partial Association in Three-way Contingency Tables." Journal of the Royal Statistical Society, ser. B (Methodological), 31 (3): 486-98.

- 1972. "A Modified Multiple Regression Approach to the Analysis of Dichotomous Variables." American Sociological Review 37 (February): 28-46.

Hahn, Harlan. 1970 "Correlates of Public Sentiments about War: Local Referenda on the Vietnam Issue." American Political Science Review 54 (December): 1186-98.

Harris Survey Yearbook of Public Opinion, 1970: A Compendium of Current American Attitudes. 1971. New York: Harris.

Hoopes, Townsend. 1969. The Limits of Intervention. New York: McKay.

Hyman, Herbert. 1954. Interviewing in Social Research. Chicago: University of Chicago Press.

Modigliani, Andre. 1972. "Hawks and Doves, Isolationism and Political Trust: An 
Analysis of Public Opinion on Military Policy." American Political Science Review, in press.

Mueller, John E. 1971. "Trends in Popular Support for the Wars in Korea and Vietnam." American Political Science Review 65 (June): 358-75.

Oberdorfer, Don. 1971. Tet! New York: Doubleday.

Robinson, John, and Solomon Jacobson. 1969. "American Public Opinion about Vietnam." In Vietnam: Some Basic Issues and Alternatives, edited by Walter Isard. Cambridge, Mass.: Schenkman.

Schuman, Howard, and Jean M. Converse. 1971. "The Effects of Black and White Interviewers on Black Responses in 1968." Public Opinion Quarterly 35 (Spring): 44-68.

Stouffer, Samuel A. 1955. Communism, Conformity, and Civil Liberties. New York: Doubleday.

Verba, S., R. A. Brody, E. B. Parker, N. H. Nie, N. W. Polsby, P. Ekman, and G. S. Black. 1967. "Public Opinion and the War in Vietnam." American Political Science Review 61 (June): 317-33. 